\title{
The Analysis of the Effect of Job Burnout on Job Satisfaction with Social Support as a Moderating Variable
}

\author{
Ni Nyoman Sri Rahayu Damayanti ${ }^{1 *}$, Made Pratiwi Dewi ${ }^{2}$ \\ Universitas Warmadewa, Denpasar-Bali, Indoensia \\ \{rahayudamayanti8@gmail.com $\left.{ }^{1}\right\}$
}

\begin{abstract}
In the midst of competition with private television, the workers must work optimally. Work pressure and high demands often make workers experience work fatigue, both physically and emotionally. Job burnout is a condition that is believed to be able to make a person more pessimistic in facing his job. This is believed to have an effect on one's job satisfaction. Social support is one aspect that is believed to be able to weaken the negative relationship that arises between job burnout and job satisfaction. This study aims to examine the effect of job burnout on job satisfaction with social support as a moderating variable. The data was collected by distributing questionnaires to respondents. The respondents are the employees of the Indonesian Broadcasting Institute, Bali Station. The research instrument test was carried out by testing the validity and reliability. After that, a classical assumption test will be carried out in the form of normality test, heteroscedasticity test, and multicollinearity test. After being freed from the problems of classical assumptions, it will be followed by moderation regression analysis techniques. The results showed that job burnout had an effect on job satisfaction. The next results show that social support is able to moderate the effect of job burnout on job satisfaction.
\end{abstract}

Keywords: Job Burnout; Social Support; Job Satisfaction.

\section{Introduction}

The television industry is one of the industries that often concerns the public. The television industry has a very significant influence on the formation of individual characters who watch their shows. Both state-owned television and private television are expected to provide broadcasts that are able to educate, present information, and provide entertainment without violating the applicable broadcasting regulations in Indonesia. Televisi Republik Indonesia (TVRI) is a television industry that organizes television broadcasting activities, is independent, neutral, non-commercial, and serves to provide services for the benefit of the public (Government Regulation No. 13/2005). The television industry, especially private television, has its own dilemma between pursuing ratings and revenue or sticking to idealism. This is a challenge for TVRI to stay afloat in providing impressions that are able to educate the public amid the rise of television broadcasts that tend to provide entertainment with ratings as the main objective. The importance of TVRI's role and duties makes its workers have to work optimally. High work pressures and demands are not uncommon for workers to experience work fatigue both physically and emotionally. 
[1] states that work fatigue or job burnout is a reflection of emotional fatigue, lack of energy, and body fatigue that can lead to low performance of a person. The condition and environment of the workplace is one of the factors that contributes to the onsaning of job burnout in workers. This condition can also cause an individual to become more pessimistic in the face of his or her work. This is believed to affect a person's job satisfaction. Each employee has a different level of job satisfaction according to the value system that applies to him or her. Mohammad Wexley and Yukl [2] stated job satisfaction is how employees feel about their work. These feelings can be favorable and unfavorable depending on how employees assess aspects of job satisfaction itself. Low job satisfaction will have an effect on a person's decrease in work performance. The decrease in employee performance will have an impact on the decrease in the organization's work performance. The president of the American Institute of Stress at New York Medical College states that losses from workplace stress in the United States are estimated at between US\$ 200 and US\$ 300 billion eachs. This is assessed through employee absence, employee turnover, direct medical expenses, employee compensation, resulting in decreased productivity, work accidents, and so on [3]. The data indirectly shows that the management of the organization's human resources is an important aspect to support the achievement of the organization's objectives.

Job burnout on employees is believed to have a variety of negative impacts for the company. In order to minimize the on-site job burnout in employees, it requires attention and support not only from the company in which they work but also from the surrounding environment. Social support is considered able to suppress employees' work stress. Social support is the availability of social relationships, whether coming from the work environment or from outside the employee's work environment. Social support can come from coworker, employer, family, or friends. Social support can reduce work stress and minimize the likelihood of health problems for an individual [4]. This support is believed to suppress the negative impact that arises between job burnout and job satisfaction.

This research was conducted to confirm previous research on personality traits that affect individual job satisfaction. This is because individual job satisfaction is one of the things that affects their performance. Based on this, it is necessary to know this research is analyzing the effect of job burnout on job satisfaction with social support as a moderating variable. The formulation of the problems in this study is as follows: Does job burnout negatively affect job satisfaction?, Is social support able to moderate the relationship between job burnout on job satisfaction?

\section{Theoritical Framework}

\subsection{Job burnout}

Leiter \& Maslach suggests that burnout is defined as emotional fatigue syndrome, depersonalization, and a sense of personal decline, achievement, which can occur in individuals working with people in the same capacity [5]. Cordes \& Dougherty (1993); Masclah (1982) in Murtiasari (2006: 5), explains that the term burnout was first put forward by [6], which is a representation of pschycological stress syndrome that indicates a negative response as a result of work pressure. Factors that can affect burnout can be categorized into two categories, namely internal and external factors. Internal factors can be gender, age, education, and marital status. External factors can include overload, role conflict, social 
support, physical condition of the workplace, company management and occupation characteristics [7].

\subsection{Social Support}

Social support is an interpersonal transaction involving assistance in the form of instrument support that individuals receive as members of social networks (House and Wells, 1987 in Russell et, al, 1989). Social support is especially important for supporting and assisting individuals if they are unable to do their own work. This assistance is believed to support the smooth running of the organization. [4] also stated that social support is an act that helps or helps by engaging positive aspects of attention, emotion, information, and judgment. Social support can reduce the burden or problems a person faces. Social support can be emotional support, instrumental support, and information support [8].

\subsection{Job Satisfaction}

Job satisfaction is defined as a combination of psychological and environmental circumstances that cause a person to be satisfied with his or her work. Job satisfaction represents positive or negative feelings arising from his work [9]. Job satisfaction describes the feeling of one's achievements and success in work. Spector [10] states there are three important aspects of job satisfaction. The first aspect is that an organization must be based on humanitarian values, such as mutual respect and respect for fellow workers. The second aspect is that a person's job satisfaction will have an effect on his or her behavior when conducting an organization's business activities. The third aspect is that job satisfaction can serve as an indicator of organizational activities.

\subsection{Research Hypothesis}

Individuals who experience job burnout tend to show a negative response as a result of the pressures of their work. This condition can be exacerbated by overload, role conflicts, and the absence of support from the individual environment. High job burnout will be illustrated through both physical and emotional fatigue [5]. This will affect the decrease in work spirit so that it will negatively affect one's job satisfaction. Decreased job satisfaction can lead to a decrease in individual work performance. Decreased individual work performance will contribute to a decrease in organizational performance. Station.

$\mathrm{H}_{1}$ : Job burnout negatively affects job satisfaction of sthe employee of TVRI, Bali

Social support is one of the external factors that is believed to weaken the negative relationship between job burnout and job satisfaction. Social support can come from within the workplace or from outside the workplace. Support from within the workplace can be support from fellow employees or from employers. Out-of-work support can come from spouses, family, or friends. Social support can reduce the burden or problems faced by a person [8]. Individuals who get support will be better able to manage the stress level at work. This will have an effect on improving feelings and atmosphere when working. A conducive work atmosphere is believed to contribute positively to individual job satisfaction.

$\mathrm{H}_{2}$ : Social support moderates the relationship between job burnout and job satisfaction of the employees of TVRI Bali Station. 


\section{Method}

The research site was conducted at the Televisi Republik Indonesia, Bali Station on 2020.

The population in this study was a permanent employee who work at the TVRI, Bali Station. The population in this study was 163 employees. The sampling technique used is a saturated sampling technique, by using the entire population as a research sample. There were 163 employees in this study sample.

1) Job Satisfaction (Y)

According to Robbins [11], job satisfaction is defined as an individual's general attitude towards his or her work. Employees with high levels of job satisfaction show a positive attitude towards their work, while employees who are dissatisfied with their work will show a negative attitude towards their work. Job satisfaction can be measured by several dimensions, including opportunities to develop themselves (promotion), satisfaction with pay or compensation, working conditions, and relationships with colleagues and supervisors or supervisors [11].

2) Job burnout (X1)

Leiter \& Maslach suggests that burnout is defined as emotional fatigue syndrome, depersonalization, and a sense of personal decline, achievement, which can occur in individuals working with people in the same capacity [5]. Job burnout is measured on a Maslach Burnout Inventory (MBI) scale consisting of 22 statement items.

3) Social Support (X2)

Social support is an act that helps or helps by engaging positive aspects of attention, emotion, information, and judgment [4]. The dimensions of social support used in this study are peer support, support from superiors, and support from a life partner or family.

The data collection method in this study uses questionnaire techniques. The questionnaire was distributed directly to respondents who in this case were permanent employees working at the TVRI, Bali Station. Research instruments are statement items that are included in the questionnaire. The instruments were tested by validity tests and reliability tests. After that, tabulating the data based on the respondent's answer then change it from ratio data to interval data. The transformation technique used is the Method of Succesive Interval. The next step is to test classical assumptions test in the form of normality, multicholinearity, and heteroskedasticity tests. Once the data is free from the classical assumption problem, the test can proceed to the moderation regression analysis stage 


\section{Results and Discussion}

Table 1. Respondents Characteristic

\begin{tabular}{|c|c|c|c|}
\hline Number & Description & Amount & Percentage \\
\hline \multirow[t]{4}{*}{1} & Gender & & \\
\hline & Female & 73 & $61 \%$ \\
\hline & Male & 46 & $39 \%$ \\
\hline & Total & 119 & $100 \%$ \\
\hline \multirow[t]{5}{*}{2} & Age & & \\
\hline & $21-30$ years old & 31 & $26 \%$ \\
\hline & $31-40$ years old & 49 & $41 \%$ \\
\hline & $41-50$ years old & 39 & $33 \%$ \\
\hline & Total & 119 & $100 \%$ \\
\hline \multirow[t]{4}{*}{3} & Marital Status & & \\
\hline & Unmating & 42 & $35 \%$ \\
\hline & Married & 77 & $65 \%$ \\
\hline & Total & 119 & $100 \%$ \\
\hline \multirow[t]{5}{*}{4} & Level of Education & & \\
\hline & Diploma & 11 & $9 \%$ \\
\hline & S1 & 82 & $69 \%$ \\
\hline & $\mathrm{S} 2$ & 26 & $22 \%$ \\
\hline & Total & 119 & $100 \%$ \\
\hline
\end{tabular}

The respondents in this study are 119 people. Based on the results of the data analysis, while the characteristics of respondents in this study were mostly women as much as $61 \%$. The majority of respondents had a range of 31 to 40 years of age of $41 \%$. A total of $65 \%$ of respondents had married. The majority of respodent education level is bachelor as much as $69 \%$.

\subsection{Validity Test Results}

The results of the instrument test showed that all instruments were valid with correlation coefficient values greater than 0.3 .

\subsection{Reliability Test Results}

A variable is reliable if the cronbach's alpha value is greater than 0.60 . The results of the analysis showed that cronbach's alpha value of each of the variable job burnout, social support, and job satisfaction were $0.979 ; 0,933$; and 0.960 . the result showed that all of the instruments were reliable.

\subsection{Classical Assumption Test Result}

The distribution of the data was normal with an asymp.sig (2-tailed) value of 0.707 . The heteroskedasticity test is performed with the Glejser test which is to regres the residual absolute value of the model estimated against an independent variable. If the level of significance is greater than the alpha level $(0.05)$, then it is said that the regression model does not contain heteroskedasticity problems. The results showed that job burnout and social support variables had significance scores of 0.258 and 0.273 indicating that there were no heteroskedasticity issues. 


\subsection{Moderation Regression Analysis Results}

Table 2. Moderation Regression Analysis Results

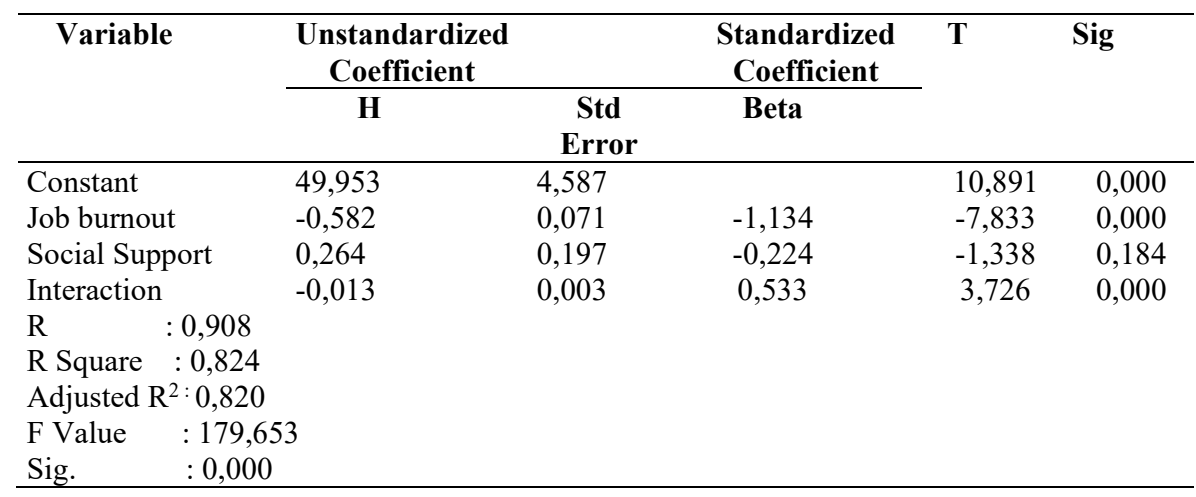

Based on the results of the analysis, this research model is worth to use. This is shown from $\mathrm{F}$ significance value of $0.000 .82 .4 \%$ of job satisfaction variable are affected by job burnout variable. The remaining $17.6 \%$ is influenced by other variables outside this research, such as financial rewards, work motivation, work environment, and other variables. Hypothetical test results will be described as follows.

\section{Job Burnout Negatively Affects Employee Job Satisfaction of TVRI Bali Station}

The results showed that the B value and the value of significance were -0.582 and 0.000 . These results show that the first hypothesis is accepted that job burnout negatively and significantly affects employee job satisfaction. The results of this study are in line with Ishwardhani's research, et al (2019). Individuals with job burnout will be characterized by feeling tired, reduced work effectiveness, low work motivation and often dysfunctional behavior in the workplace. This situation will develop progressively. [6] states that job burnout is a representation of pschycological stress syndrome that shows a negative response as a result of work pressure. Negative responses such as performing dysfunctional behaviors will decrease a person's performance. This will certainly contribute to the decline in the quality of work. When this happens, it will have an effect on the decrease in job satisfaction in question. [12] defines job satisfaction as a pleasant emotional attitude and loves her job. This will be difficult to feel for individuals with high burnout because in general the person in question often shows a negative response due to the pressure of the work experienced.

\section{Social Support Moderates the Relationship Between Job Burnout and Job Satisfaction of Employees of TVRI Bali Station}

The results showed the value of interaction significance was 0.000 . This shows that the second hypothesis is accepted that social support is able to moderate the relationship between job burnout and job satisfaction. [4] stated that social support is a helpful or helpful act involving positive aspects of attention, emotion, information, and judgment. Social support can be emotional support, instrumental support, and information support [8]. Social support provided to an individual with high work pressures is able to make the person more able to adapt to the situation. Individuals with an emotionally supported, instrumental and wellinformed social environment when they need it, show lower levels of stress and depressive symptoms in the face of life events compared to those who [4]. The individual will work with 
emotions that tend to be more stable, so that the negative impacts that arise from work pressures can be further minimized. This condition is believed to weaken the negative effect of job burnout on a person's job satisfaction.

\section{Conclusion}

The results showed that job burnout had a negative and significant effect on job satisfaction. Subsequent results showed that social support was able to moderate job burnout relationships with job satisfaction.

\section{References}

[1] M. Gorji, "The effect of Job burnout Dimension on Employee Performance," Int. J. Soc. Sci. Humanit., p. 243:246, 2011.

[2] Wexley and Yukl, Perilaku Organisasi dan Psikologi Personil. Jakarta: PT. Rineka Cipta, 1997.

[3] F. Luthans, Perilaku Organisasi 10th Edisi Indonesia. Yogyakarta: ANDI, 2006.

[4] S. Cohen and T. A. Will, "Stress, Social Support, and The Buffering Hypothesis," Psychol. Bull., vol. 98, pp. 310-357, 1985.

[5] M. P. Leiter and M. C, "The Impact of Interpersonal Environment of Burnout and Organization Commitment," J. Organ. Behav., vol. 9, pp. 297-308, 1998.

[6] H. Freudenberger, Burnout: The High Cost of High Achievment. New York: Anchor Press Doubleday and Company Inc, 1980.

[7] K. Ahola, Occupational Burnout and Health Helsinki. Yampereen Yliopistopaino Oy- Juvenes Print, 2007.

[8] A. Murtiningrum, "Analisis Pengaruh Konflik Pekerjaan-Keluarga Terhadap Stress Kerja Dengan Dukungan Sosial Sebagai Variabel Moderasi (Studi pada Guru Kelas 3 SMP Negeri di Kabupaten Kendal)," Universitas Diponegoro Semarang, 2006.

[9] K. Davis and J. W. Newstrom, Perilaku Dalam Organisasi. Jakarta: Erlangga, 1985.

[10]P. E. Spector, Job Satisfaction. Thousand Oaks: CA: Sage Publications, Inc, 1977.

[11]P. S. Robbins, Perilaku Organisasi. Jakarta: PT Indeks, 2003.

[12]P. S. M. Hasibuan, Manajemen Sumber Daya Manusia. Jakarta: PT. Bumi Aksara, 2015. 